\title{
Online Branding in Newspapers: A Conceptual Model
}

\author{
Lassaad Ghachem
}

FSEGM, Mahdia, Tunisia

\begin{abstract}
Online media branding strategies is growing at a very fast pace and is increasingly adopted not only by pure players companies but also by traditional firms. In the digital newspapers sector, online news are becoming the most required services from Internet users and their sites are among the most visited on the web. Researches on online branding of newspapers seem incomplete and there is still a lack of investigations and studies about newspapers e-brands aspects (exp: content, interactivity, web site attributes...). Our aim is to develop a conceptual model allowing a better understanding of the newspapers e-brands aspects and their relations with levels of substitutability and reader motivations.
\end{abstract}

Keywords: Newspapers, e-brands, reader motivation and substitutability.

\section{Introduction}

Ten years after the bursting bubble of the Internet, media groups are making a strong comeback in the web landscape. Given the important consumption of media products and the growing spread of Internet use, the Web becomes an inevitable gateway for media firms. Similar to other sectors, the constant development of the Internet has given rapid changes in the distribution of informational products and services. It was also at the origin of important transformations in relationships between media companies and their audience. Press, radio and television have more and more content and editorial expertise with strong brand names. However, despite the introduction of some successful development models, many media firms still lack clear strategic visions about the use of Internet and web based technologies. There is also a lack of researches on online media branding and strategies, and substitutability between offline and online distribution.

\section{Media and web based technologies}

ICT innovation has transformed traditional media distribution through more efficient production, new forms of interactions, transformation of relationships between media companies and their audience conventional and new conceptions of certain activities and businesses (Blackman, 2004; Forrester Research, 2004; Cheong and Park, 2005). Besides, Internet introduced new players to the web landscape, gave more choices to consumers and gave the opportunity to each one to publish and

Copyright (C) 2011 Lassaad Ghachem. This is an open access article distributed under the Creative Commons Attribution License unported 3.0, which permits unrestricted use, distribution, and reproduction in any medium, provided that original work is properly cited. Contact author: Lassaad Ghachem E-mail: lassaad.ghachem@neuch.ch 
broadcast (Blackman, 2004). Industries like newspapers, are for example one of the most affected by Internet and online distribution (Flaviàn and Gurrea, 2006). Moreover, Blackman (2004) added that innovations like broadband networks, content management systems or peer-to-peer communications will have an impact in shaping the media sector.

On the other hand, England and Finney (2002) mention that Online editing of web site content is the new branch of journalism and publishing thanks to interactivity of new media and internet. Furthermore, customers will need more for personalized and customized products and services (Blackman, 2004; Peters, 1998; Nielsen, 2005). As a consequence, many aspects of the media sector will be influenced.

\section{Interactivity}

Having been one of the most important ideas of the cybernetic theory (developed by Norbert Wiener), interactivity is becoming the principal aspect characterizing the new media and the Web. Interactivity integrates digital media into a structured digital computerized environment to allow people to interact with the data for appropriate purposes (England and Finney, 2002).

Lamizet and Silem (1997) noted that it is in the interactivity that lies the media revolution: media evolution is essentially characterized by a more developed capacity of interactivity. For Heeter (1989), increased interactivity is seen as a primary distinction of new media (such as Networked Multimedia, Internet, WWW, interactive TV, e-games, virtual worlds, e-learning, eentertainment etc.).

Jensen (1998) argues that the definition of interactivity in media studies and computer science is mainly based on three ways: prototypic examples, criteria (characteristic that must be fulfilled) and continuum models. In this article, we will use the last way to define the concept of interactivity: continuum (based on the degree of interactivity). As Heeter (1989) noted, interactivity is a multidimensional concept and can be explained under varying degrees. Jensen (1998) summarizes different inputs of authors in term of the number of dimensions they used to define interactivity (see table 1).

Table 1: Number of Dimensions Used to Define Interactivity, Adapted from Jensen (1998)

\begin{tabular}{|l|l|}
\hline One dimension & Rogers (1986) ; Schrape (1995) ; Sheizaf Rafaeli (1988). \\
\hline Two dimensions & Szuprowicz (1995) \\
\hline Three dimensions & Laurel (1986 \& 1990) \\
\hline Four dimensions & Goertz (1995) \\
\hline N Dimensions & Heeter (1989) \\
\hline
\end{tabular}

\section{Substitutability and Remediation}

Thanks to interactivity, Web site offers a facilitated communication, a customized information, images manipulations and entertainments for the customer (Fiore and Jin, 2003). Web site can be considered as a full new medium with its specific aspects and characteristics like networking, multimediality or hypertext and can as a network medium accept a dialogic or conversational traffic pattern (Nielsen, 2005). The author added that the web must be considered as an interactive multimedium and not only, as an online user interface. However, this full status presents in some cases a cannibalistic effect between on line and off line media. Indeed, authors like Rathmann (2002) noted the fact that the duality of the news media in both physical and digital environments can cause cannibalization. Other authors (Bolter andGrusin, 1999; Everett, 2003), mention the remediation aspect of the web site: it can remediate existing media. Substitutability and remediation will generate more interests 
particularly with evolution of interactive media like digital television or publishing on demand.

\section{Online Newspapers}

ICT and internet is transforming traditional media and publishing: better efficiency in production, wider choices for consumers and more forms of distribution (Blackman, 2004). The evolution of online newspapers is considered by Li (2006) as one of the most spectacular success story of the internet. Flavia'n \& Gurrea (2006) added that the newspaper industry is among those that have been most affected by the development of the internet.

"Rather than becoming the replacement for its print version, as so many predicted it would be, the Internet has afforded newspapers a unique opportunity to leverage the news and information and the interested audience into a new medium" (John F. Sturm, The Newspaper Association of America President and CEO) ${ }^{1}$.

Kanaujia \& Srivastava (2003) added that Internet is becoming an interesting area for news addicted, allowing them to gather information from all over the world. Besides, according to Flavia'n \& Gurrea (2006), the usage of Internet as a channel for online publishing newspapers has made significant changes in the sector. Media groups generally and newspapers industry in particular, does not limit their offer to the print medium, they also initiate new services online (Kanaujia \& Srivastava, 2003). In this context, companies operating in this sector are faced to new challenges (Dans, 2000). Under the view of $\mathrm{Li}$ (2006), despite the increasing influence of electronic newspapers, it has modest impact on the regression of newspaper circulation. The author found interactive processes and relationships between online newspapers and printed versions. However, Greer and Mensing (2003) found a difference regarding the way of work of online and offline medium. Traditional editorial offices would be slower than electronic ones. But in term of contents, Kanaujia \& Srivastava (2003)

\footnotetext{
${ }^{1}$ April 30, (C) 2002 Media Life
}

argued that online newspapers, as the printed ones, provide content their readers want and the quality audience that advertisers look for. Indeed, much like a printed version, design of electronic newspaper affects reader interests and priorities (Li, 2006). Flavia'n \& Gurrea (2006) talked about the specific advantages of online journalism. According to them, the most important revolution of online media news is related to the rapidity with which news get to the reader, the low cost of information diffusion and the occasion to create more direct contact and interaction with readers. This reader has much greater choice, particularly with the entry of new players in the online newspapers sector (Blackman, 2004).

\section{Online Branding of E-newspapers}

The most common definition of the brand concept is developed by Kotler (1994):

"A brand is a name, term, sign, symbol or design, or a combination of them, intended to identify the goods or services of one seller or group of sellers and to differentiate them from those of the competitors".

Brands help firms to establish a unique identity enabling them to attract a large amount of repeat business (Ibeh et al., 2005) and let consumer identify product/service in the market (Cooke, 1996). War and Lee (2000) added that brands become more important nowadays because of the surplus of information: Brand enables customer to save time, by reducing search costs. In an electronic context, online branding is being essential.

Simmons (2007) noted that, with dynamic challenges, internet made branding more complex.Moreover, online branding presents enough challenges and opportunities (Rowley, 2004). For Da Silva \& Alwi (2008), even if issues concerning consumers in an online and offline context are the same, online branding is more focalized on personalization, customer service, ease of use and security. Rowley (2004) argues that in an online environment, "physical interaction is 
reduced and benefits must be distilled and captured in a way that can be communicated over the wires". Furthermore, the lack of sensory interaction with Internet and worries about security make the construction of strong e-brands more complex (Simmons, 2007). The author also added that internet branding strategies are more difficult because of the real-time interaction and marketplace crowding. But according to Rowley (2004), online branding is more important for high value products, which represents the infrequently purchased and highly differentiated items. In these circumstances, companies must have a real ebranding strategy and establish rapidly an internet label to gain the first mover advantage (Doyle, 1998). The development of e-branding strategies also helps firms creating some distinctiveness (Kenney and Curry, 1999), building stronger relationships with unique messages (Ibeh et al., 2005). These strategies need better targeting and more understanding and learning about the online customer (Kierzkowski et al., 1996). In their study in 2008, Da Silva \& Alwi confirmed the fact that building relationships is vital online and consumers are co-creators of brands. According to the same authors, online company has to "listen" more to its customers. Simmons (2007) developed a Four Pillars of e-Branding framework. It provides the basis for e- branding strategies: Marketing communication, Understanding Customers, Interactivity and Content. Despite these findings, it is still imperative to study more about branding in digital environment. According to Merrilees \& Fry (2002), there are few empirical studies focusing on the effects of internet on firm's brand image and there is a lack of strong confirmation about what drives value on internet. Rowley (2004) added the fact that it is important to explore some of the potential impacts of online channels for branding strategy and the difficulty to differentiate, the practical and theatrical aspects between online and offline branding.

According to Blackman (2004), "Media companies will rely heavily on being the trusted gatekeeper of information. In this context, branding enables users to recognize trustworthy information sources and, therefore, to deal with the problem of too much choice". Moreover, the technology evolution, has attracted new players (Blackman, 2004) and increased the number of content providers and competitors (Ots, 2008). However, as stated by (ChanOlmested, 2006), media brand management is far from completely developed, and its practices are still not enough strategic. Branding in this sector is seen to be quite difficult and more complicated with some particularities (Siegert, 2008). Furthermore, brands allow the creation of quality and services continuity, the separation of products and firms from their rivals and the development of strong relationship with consumer (Siegert, 2008). The uniqueness of branding in media is resumed by Ots (2008):

a) Media firms operate on dual markets (building brands toward consumers and at the same time selling the effects of this brand loyalty to advertisers). b) Media companies through their own products powerful massmarketing tools can both build the existing brand and help launch new brands or new products. With the growth of online and offline brands, the web is becoming an integral part of the modern "brandscape" (Christodoulides \& Chernatony, 2004). Brand's Internet success needs an effective online presence (Hanson, 2000). This is also true for media and newspapers sectors. In fact, Nielsen (2003) argues that electronic newspapers are among the most usually required and visited web sites on Internet. Siegert (2008) has noted that brand management has become a fundamental managerial task and researchers are encouraged to explore its implications for media firms.

\section{Conceptual Model}

Researches on online branding of newspapers seem incomplete and there is still a lack of investigations and studies about newspapers e-brands aspects (exp: content, interactivity, web site attributes...). Our aim is to develop a conceptual model (figure 1) allowing a better understanding of the newspapers e-brands aspects and their 
5 Communications of the IBIMA

relations with the online reader motivations and their impact on level of substitutability.
With our conceptual framework, we try to contribute to the wider understanding of ebranding of newspapers.

\section{Figure1: Conceptual Model}

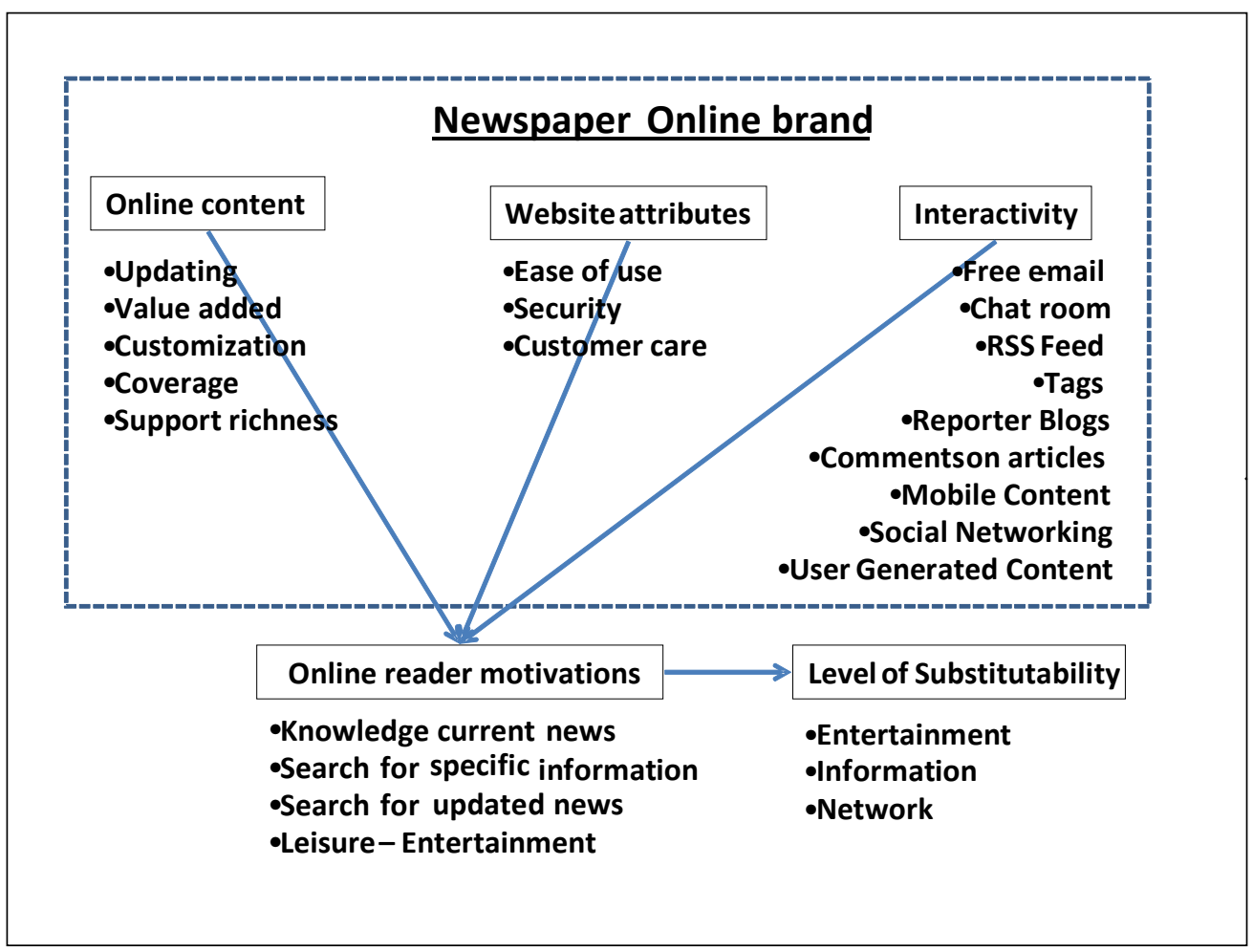

\section{References}

Blackman, C. (2004). "Paying the Price: the Future for Europe's Media Sector," Foresight, Volume 6, Number 5.

Bolter, J.D. \& Grusin, R. (1999). 'Remediation: Understanding New Media,' MIT Press, Cambridge, MA.

Chan-Olmsted, S. M. (2006). Competitive Strategy for Media Firms: Strategic and Brand Management in Changing Media Markets, Lawrence Erlbau associates, Mahway: New Jersey

Cheong, J. H. \& Park, M.-C. (2005). "Mobile Internet Acceptance in Korea," Internet Research, Vol. 15 No. 2, pp. 125-40.
Christodoulides, G. \& Chernatony, L. D. (2004). "Dimensionalising on- and Offline Brands' Composite Equity," Journal of Product and Brand Management, Volume 13, Number 3, pp. 168-179(12).

Cooke, P. (1996). 'The Branding and Positioning of Tourist Destinations,' Tourism Intelligence Papers, A, pp. 101-6.

Da Silva, R. V. \& Alwi, S. F. S. (2008 ). “Online Brand Attributes and Online Corporate Brand Images" European Journal of Marketing, Vol. 42 No. 9/10, pp. 1039-1058

Dans, E. (2000). "Internet Newspapers: are Sme More Equal than Others?," International Journal on Media Management, Vol. 2 No. 1, pp. 4-13. 
Doyle, P. (1998). Marketing Management and Strategy, 2nd ed., Prentice-Hall, Harlow

Everett, A. (2003). 'Digitextuality and Click Theory,' Theses on Convergence Media in the Digital Age, Everett, A. and Caldwell, J.T. (Eds)., New Media, Theories and Practice of Digitextuality, Routledge, New York, NY, London.

Fiore, A. M. \& Jin, H.- J. (2003). “Influence of Image Interactivity Technology on Approach Responses towards Online Retailer," Internet Research: Electronic Networking Applications and Policy, 13(1)., pp.33-48.

Flavia'n, C. \& Gurrea, R. (2006). "The Choice of Digital Newspapers: Influence of Reader Goals and User Experience," Internet Research, Vol. 16 No. 3, pp. 231-247.

Goertz, L. (1995). 'Wie interaktiv sind Medien? Auf dem Weg zu einer Definition von Interaktivität,' Rundfunk und Fernsehen, no. 4.

Greer, J. D. \& Mensing, D. (2003). "The Evolution of Online Newspapers: a Longitudinal Content Analysis, 1997-2003," paper presented at the Meeting of the Association for Education in Journalism and Mass Communication, Kansas City, MO, August.

Hanson, W. (2000). 'Principles of Internet Marketing,' South-Western College Publishing, Cincinnati, $\mathrm{OH}$

Heeter, C. (1989). 'Implications of New Interactive Technologies for Conceptualizing Communication,' Jerry L. Salvaggio \& Jennings Bryant (eds.).Media Use in the Information Age: Emerging Patterns of Adoption and Consumer Use, Hillsdale, New Jersey.

Ibeh, K. I. N., Luo, Y. \& Dinnie, K. (2005). “Ebranding Strategies of Internet Companies: Some Preliminary Insights from the UK," Journal of Brand Management, Vol. 12 No. 5, p. 355 .
Jensen, J. F. (1998). 'Interactivity: Tracking a New Concept in Media and Communication Studies,' Nordicom Review, 19, 1, 185-204.

Kanaujia, S. \& Srivastava, R. (2003). “Online Newspapers: News on Fast Track," Library Hi Tech News, Volume: 20 Issue: 10

Kenney, M. \& Curry, J. (1999). "E-commerce: Configuration," Economy Paper , University of California, Berkeley, CA.

Kierzkowski, A., McQuade, S., Waltman, R. \& Zelsser, M. (1996). "Marketing to the Digital Consumer," The McKinsey Quarterly, Vol. 79 No. 3, pp. 5-21.

Kotler, P. (1994). 'Marketing Management: Analysis, Planning, Implementation and Control,' Prentice-Hall International, Englewood Cliffs, NJ.

Lamizet, B. \& Silem, A. ( 1997). Dictionnaire Encyclopédique des Sciences de l"information et de la Communication, Paris, Éditions Ellipse, 590 p., ISBN 2-7298-4766-9

Laurel, B. (1986). 'Interface as Mimesis,' D.A. Norman \& S. Draper (eds.). User Centered System Design: New Perspectives on HumanComputer Interaction, Hillsdale: Lawrence Erlbaum Associates.

Laurel, B. (1990). "Interface Agents: Metaphors with Character," Brenda Laurel (ed.).The Art of Human- Computer Interface Design, Reading, Mass.: Addison-Wesley.

Merrilees, B. \& Fry, M.-L. (2003). “E-trust: the Influence of Perceived Interactivity on ERetailing Users," Marketing Intelligence and Planning, Vol. 21 No. 2, pp. 123-8.

Nielsen, H. J. (2005). “New Media and New Roles of Librarianship: Illustrated by a Literary Website of Danish Libraries," New Library World, Vol. 106, Issue 11-12

Nielsen, J. (2003). "Usability 101," available at: www.useit.com/alertbox/20030825.html 
7 Communications of the IBIMA

Ots, M. (ed.). (2008). "Media Brands and Branding," Jibs Research Reports 2008-1: Jönköping International Business School

Peters, L. (1998). "The New Interactive Media: One-To-One, but Who to Whom?," Marketing Intelligence \& Planning, Volume: 16.

Rathmann, T. (2002). "Supplement or Substitution? The Relationship Between Reading a Local Print Newspaper and the Use of its Online Version," Communications, Vol. 27, pp. 485-98.

Rogers, E. M. (1986). 'Communication Technology: The New Media in Society,' New York.

Rowley, J. (2004). “Online Branding,” Online Information Review, Volume 28, Number 2, 2004 pp. $131-138$

Schrape, K. (1995). 'Digitales Fernsehen. Marktchancen und ordnungspolitischer Regelungsdedarf,' München.

Siegert, G. (2008). "Self Promotion: Pole position in Media Brand Management," JIBS Research Reports, 2008-1: Jönköping International Business School.

Simmons, G. J. (2007).'“i-Branding”: Developing the Internet as A Branding Tool,' Marketing Intelligence \& Planning, Vol. 25 No. 6, 2007 pp. $544-562$

Szuprowicz, B. O. (1995). Multimedia Networking, New York: McGraw-Hill.

Ward, M. R. \& Lee, M. J. (2000). "Internet Shopping, Consumer Search and Product Branding," Journal of Product and Brand Management, Vol. 9 No. 1, pp. 6-20.

Xigen, L. (2006). Internet Newspapers: The Making of a Mainstream Medium, Lawrence Erlbaum Associates, Mahwah, NJ. 